\title{
'Now the Scene appears chang'd': Amabel Countess De Grey, Lifecycles and the Visitor Experience of English Watering Places, 1775-1826
}

Visiting Tunbridge Wells in 1790 as a wealthy independent widow, Amabel Countess De Grey was unimpressed by the spa she had first seen as a newly married young woman:

I remember when I first came here - no less than 15 Years ago, I was agreeably surprised at finding the Place so much surpass my Expectation. There was a Vivacity \& an Ease in it that pleas'd. I convers'd with new Acquaintance, and was amus'd with the Convenience of a Circulating Library, \& the exploring the Beauties of the neighbouring Country seem'd to afford a constant Fund of Entertainment. Now the Scene appears chang'd, there are very few People whom I know or care for, the Library appears empty and dull, the Country indeed is always beautiful, but the Weather is uncertain.1

Whilst in previous years, Tunbridge Wells had been a vibrant centre for leisure and pleasure that had attracted royalty and the fashionable elite to drink its chalybeate waters, by 1790 the spa had entered into decline. With visitor numbers falling and the resort transitioning into a place for genteel residence, Amabel judged the social scene 'dull' and the amusements lacking: even the weather failed to meet expectations. But, as this article will demonstrate, Amabel's dissatisfaction was not merely a result of the spa's changed visiting company and physical environment: the Countess's own motivations for visiting the resort and the activities that she engaged in whilst there had also changed significantly over the course of fifteen years. As will be argued, these changes resulted from Amabel reaching different stages in her lifecycle: attitudes, activities and social networks evolved according to a wide range of intersecting factors, including age, marital status, health and personal character.

Through a study of Amabel's diaries and correspondence, this article will explore the visitor experience of English watering places between 1775 and 1826. Born in 1751, Amabel HumeCampbell [née Lady Amabel Yorke], suo jure Countess De Grey (1751-1833) entered into an aristocratic, scholarly and politically active High-Whig family. She was the daughter of Philip Yorke, second Earl of Hardwicke, eldest son of the Lord Chancellor (1722-1770) and Jemima Yorke, née Campbell, suo jure Marchioness Grey and Baroness Lucas of Crudwell. Amabel grew up and was privately educated between the family's estate of Wrest Park in Bedfordshire and their London residence 4 St James's Square, along with her younger sister Mary (Mary Jemima Robinson, Lady Grantham, 1757-1830). On 16 July 1772 Amabel married Alexander Hume-Campbell, Lord Polwarth 
and though the match was arranged by Amabel's parents, the couple developed a genuine affection. They had no children, however and Alexander died of consumption in 1781, aged only thirty-one. Amabel never remarried. On her mother's death in 1797, Amabel inherited her titles and considerable estates.

Passionately interested in politics and a published author, Amabel had close connections with the Bluestockings and can be seen as an intellectual figure in her own right.2 Unfortunately, Amabel was plagued by ill-health towards the end of her life, suffering from rheumatism, bilious complaints and painful teeth. Most distressing was the gradual loss of eye-sight due to the formation of cataracts, which eventually prevented reading or writing. There is, however, little to suggest that she suffered from hypochondria. Amabel died on the 4 March 1833 at her home in St James's at the age of eighty-two.

A prolific writer, Amabel opened the first volume of what were to become a series of thirtyseven diaries that spanned the majority of her adult life with the statement: 'My Design in this Book, is to write down some memorandums, of what I hear or see, most remarkable.'3 Intended as a private record, the diaries are an extremely valuable source, not only as they provide a fascinating account of fashionable and political life but also as they offer a unique insight into the leisure experiences of elite women, containing in particular daily entries detailing social and cultural activities pursed during visits made to spas and seaside resorts during the later eighteenth and early nineteenth centuries. Separated from the bulk of the family's archives, however, scholars have overlooked this valuable sources in favour of the family's extensive correspondence and attention has focused instead on Lady Hardwicke's political and Bluestocking connections.4

Identifying the motivations and inner thoughts of an individual through their written records is problematic and the possibilities and limitations of the study of personal narratives and 'life histories' is perhaps a particularly acute issue for the study of women's writing. As Harriet Blodgett has noted, 'freely speaking diarists are the exception, not the rule' and 'few women's private diaries actually contain candid accounts of the diarists' inner lives'.5 Several of the key elements addressed by this article, particularly sexual and emotional relationships, are largely absent from women's writing and 'Inevitably the most intimate thoughts and feelings go unrecorded.' 6 The texts themselves as letters and daily diary entries have their own conventions and restraints, which need to be recognized. Furthermore, none of the manuscript sources examined are 'in any simple sense an unmediated expression of the self' but, as Amanda Vickery has emphasized, 'our public performances are no less significant than our secrets'.7

Providing an account of Amabel's activities across the greater part of sixty-three years, the dairies offer the unusual scope for longitudinal analysis and allow significant insight into the 
relationship between the female lifecycle and the visitor experience of watering places. Throughout her life, Amabel spent significant time in three of the country's leading spas and seaside resorts: Bath, Margate and Tunbridge Wells. As an astute and reflective observer of resort life, Amabel's records provide invaluable insight into the social, cultural and medical life of these resorts. This article will divide Amabel's visits to resorts into three broad but distinct phases. The first encompasses the three visits of Amabel and her husband Lord Polwarth to Tunbridge Wells between 1775 and 1777 as a young, newly married couple seeking fashionable company and diversion. It will be argued that these visits also held a significant secondary motive: married since 1772 without issue, Amabel hoped to benefit from the water's reputed ability to promote fertility. After Lord Polwarth's death and during the second phase, Amabel's resort visits were guided by her father Lord Hardwicke's persistent ill-health. The widespread belief in the power of mineral and seawaters will be explored through the family's pursuit of a cure at Margate in 1781 and Bath in 1784. The third phase, from 1790 to 1826, saw Amabel regularly returning to Tunbridge Wells as a wealthy, independent widow. Amabel's frequent expressions of boredom will be used to explore how visitors expressed their dissatisfaction with the spa's society and facilities.

This analysis contributes to an emerging focus among historians on the visitor experience of watering places. The wealth of written material left by elite women in particular has been used to examine how spas emerged as feminine arenas and how they functioned as polite urban spaces. In her book Female Alliances: Gender, Identity, and Friendship in Early Modern Britain, Amanda E. Herbert has explored how spas, 'in addition to being gathering places for people of both sexes, were sites of same-sex sociability, as both women and men undertook distinct activities during their sojourns.' By using women's 'own voices and perspectives on spa life and sociability', Herbert illuminates the gendering of the spa and the different ways these spaces were used by women during this crucial period of their history.8 Together with Alison E. Hurley's 2006 article on the watering place correspondence of the Bluestockings from Tunbridge Wells, Herbert's work refocused the study of spas away from the marriage market towards the powerful female communities created in these unique social spaces. 9

This analysis of Amabel's experiences will do far more than just add another voice to these studies of the elite female spa-goer. First, it allows for a comparative analysis of spas and seaside resorts, demonstrating how the pattern of daily life and the use of space differed between the two types of watering place. Seaside resorts emerged in England from the 1720s. An evolutionary progression of the water cure, seaside resorts during the long eighteenth century shared many defining characteristics with spas: most significantly, seaside resorts aimed to replicate the spa's social and cultural model, most notably with the provision of assembly rooms, circulating libraries 
and walks. There were, however, subtle yet significant differences in the way visitors moved around seaside resorts - particularly regarding the interaction with nature - and in the structure of activities, a factor currently under-examined within the existing historiography.

Second, Amabel's records offer a new perspective on how watering places as urban and polite spaces were used by the elite female visitor. The study of spas and seaside resorts has evolved significantly from the traditional descriptions of physical environments and built facilities to consider in greater detail their importance as unique urban centres. Thriving from 1660s as multidimensional sites that combined the pursuit of health and leisure through the ritual of 'taking the waters', resorts functioned as centres of polite society, marriage markets, arenas for homosociality, venues for conspicuous consumption, and places of medical treatment. Bath, as the 'Queen of the Spas', has received the most scholarly attention. Most notably, R.S. Neale's Marxist inspired history of the city has been recently followed by two studies that interrogate Bath's image: Peter Borsay's The Image of Georgian Bath (2000) and Graham Davis and Penny Bonsall's A History of Bath (2006).10 An increasing interest in the history of medicine at the spa has led to a more nuanced understanding of the water cure itself. Perhaps most significantly, Audrey Heywood has proven the effectiveness of Bath's thermal waters in the treatment of lead poisoning, thus demonstrating the presence of actual curative properties beyond that of placebo.11

Tunbridge Wells, which founded its reputation on its rural character, offered a very different environment to its rival, Bath. Both Alan Savidge and C.W. Chalklin have offered detailed and comprehensive accounts of the physical development of the town.12 But it was Margaret Barton's 1937 Tunbridge Wells that considered in the greatest detail many of the themes that emerge most strongly within this study, most notably the importance of women's health within the culture of the spa.13 None of these studies, however, provide a complete account of the social, cultural and medical history of the spa and all are limited by their predominantly narrative structure.

The history of Margate is dominated by the work of John Whyman. Extensively and minutely researched, Whyman's 1985 thesis 'Aspects of Holidaymaking and Resort Development within the Isle of Thanet, with particular reference to Margate, c. 1736-1840' together with his sourcebook The Early Kentish Seaside, published in the same year, provides a strong foundation for the study of England's first popular seaside resort.14 Whilst Whyman's comprehensive research is likely to remain unrivalled as a local history, his focus on description rather than analysis means there remains significant scope to explore the visitor experience of the first 'popular' seaside resort.

This continuously growing body of publications dedicated to individual watering places is supported by nationwide studies. The key works remain those surveys published during the late 1970s, 1980s and early 1990s which, following example of J.A.R. Pimlott's The Englishman's Holiday 
(1947) aimed to explore the then neglected field of leisure history. Hembry's The English Spa, 15601815 (1990) remains unrivalled as a thorough and comprehensive account of the rise of England's spas, combining the precise description of individual resorts within the wider narrative of the development of watering places across this crucial period of their history. For the English seaside there emerged a number of surveys, most significantly John K. Walton's The English Seaside Resort (1983) James Walvin's Beside the Seaside (1978).15

Third, Amabel's records show the need for a more nuanced understanding of the use and importance of the water cure, particularly for women's health. Contemporaries and modern scholars alike have questioned the importance of the water cure to visitors and debate continues over the relative significance of genuine, fashionable and feigned illnesses within resort culture. Recent work on fashionable diseases has helped to extend the debate beyond Roy Porter's dismissal of the water cure as a 'charade' and spas as 'but a vast marketplace of quackery ... with the collusion of hypochondriacs and valetudinarians desperate for attention and anxious to ail fashionably' towards a more complex and balance understanding.16 Studies by Clark Lawlor, Allan Ingram and Heather Beatty in particular have advanced our understanding of such sufferers and suggest, contrary to Porter, that the prevalence of fashionable illnesses at watering places was did not negate the importance of the water cure as a medical treatment: illness may have conferred cultural capital, particularly within arenas centred round the conspicuous consumption of health, but the statusaccruing symptoms of the fashionable sufferer should not be focused on at the expense of the genuine patient.17 Neither did a patient's interaction with culturally-influenced disorders necessarily come at the expense of their sincerity. Amabel's records, by allowing for an analysis of a familygroup perceived and utilized mineral and seawaters across a long period of time contributes to this developing understanding of the medicinal role of watering places, particularly in the field of women's health.

i

Tunbridge Wells would have been a fairly obvious destination for a young, wealthy and recently married couple in the 1770s. Only thirty-six miles from London, Tunbridge Wells had emerged after the Restoration as a leading drinking spa. Once the favoured destination for Charles II's libertine court, Tunbridge Wells in the early eighteenth century had transformed into a respectable centre for polite society. The spa's reputation had been ensured by the appointment in 1735 of Richard 'Beau' Nash as Master of Ceremonies, who also held the position at Bath. With the larger spa operating a winter season, Tunbridge Wells flourished as a summer resort, with visitors attending primarily between May and October. A desire to maintain the spa's rural character, combined with disputes 
over the ownership of land in the 1730s, meant that building was restricted and largely consistent throughout the eighteenth century. Facilities centred round the Pantiles; two tree-lines walks at the end of which was the chalybeate well. When Amabel visited in the 1770s, Tunbridge Wells boasted a circulating library, coffee and tea rooms, covered walks, a number of shops selling luxury goods, and two assembly rooms: the Great Room and the Long. As Richard Onely's 1771 guidebook described, public balls were held:

...on Tuesdays at the room on the walk, and Fridays at the lower rooms; every other night in the week, (Sundays excepted, when the company generally meet to drink tea at the coffee-house) are card-assemblies at each of the public rooms alternately.18

Amabel and her husband visited Tunbridge Wells three times during the 1770s and, as part of a wider tour around England, also made a brief visit to Bath. Their first visit to Tunbridge Wells, of seventy-two days from 10 July to 20 September 1775, took place across the resort's summer season and they were accompanied by Amabel's cousin, Miss Gregory. Their visits in 1776, sixty-four days from 13 June to 15 August, followed on similar lines and the party was joined by Amabel's sister Mary for a fortnight. Their visit in 1777 was somewhat different: the couple stayed in Tunbridge Wells from 7 July to 14 August, when they then relocated to Brighton for just under a month. During this period Lord Polwarth grew increasingly unwell: the beginning of a decline in health that would eventually lead to his death four years later. During this time, Amabel's motivations for visiting resorts can be divided into two main facets: the desire for fashionable leisure and pleasure, which was openly acknowledged; and the publicly unacknowledged and unrecorded search for a cure for the couple's infertility.

Though by the 1770s the spa had begun the transition into a place of genteel residence, it was still able to attract the fashionable elite in significant numbers. On 31 July 1775 the London based Gazetteer and New Daily Advertiser was able to report that the 'Undressed Ball at Mr. Pinchbeck's Great Room on Friday last' was 'more nobly attended than any ball these season', participants including the 'The Countesses of Effingham, Pembroke and Lincoln', and the 'Prussian Minister'.19 During each stay, Amabel eagerly participated in the social and cultural activities that characterized resort life and the daily record of activities within the diaries allows a detailed picture to be constructed of how time at the resort was spent. If the week of Monday 31 July to Sunday 6 August 1775 can be taken as typical, Amabel's pastimes were as follows:

Monday, July th $31^{\text {st }}$ 
Miss G. \& I went to the Rooms.

Tuesday, Aug th $1^{\text {st }}$

Visited Mrs Carter in the Morning.

In the Evening Miss E Elliot walk'd with us round by some Woods to the Windmill.

Wednesday, Aug th $2 \mathrm{~d}$

Sr G. \& Ldy H. Ldy M, Ldy B \& Mr Douglas, \& Miss E.E. drank Tea with s, \& walk'd down to the Wells.

Thursday, Aug th 3d

Mov'd into a House lower down on Mount Ephraim in which the Bp of London lately lodg'd.

Friday, Aug the 4

We went to the undrest Ball at Fry's Rooms, after drinking Tea at Mrs Crop's with Ldy Hales \& her Daughters. Ld P had given in the Morning a public Breakfast at Mrs Vaughans Rooms.

Saturday, Aug th $5^{\text {th }}$

We all walk'd to the Rocks, (through a pleasant Valley) with Sr G. \& Ldy Heathcote, Ldy B \& Mr Douglas \& Miss E. Elliot - Went afterwards to Pinchbeck's Rooms.

Sunday, Aug th $6^{\text {th }}$

I visited Ldy Chesterfield, \& then went to Ldy Elliots; Mrs Stuart Mr Andrew Stuart, \&c were there. 20

Much of this week was spent in public, socializing with the visiting company: during this week Amabel went to one ball, visited the rooms twice, walked to the wells once and attended a public breakfast. In a letter written a couple of weeks later she wrote 'I was Five Evenings out of seven at the Rooms.'21 Amabel also, however, spent much of her time engaging in what appear to be more private gatherings with friends and acquaintances of a similar rank. Unfortunately, no evidence survives of the topics discussed, however given Amabel's intellect and particularly her interest in politics, it is likely that conversations ranged far beyond resort gossip. 
Even though she was visiting Tunbridge Wells with her husband, there was seen to be a need for Amabel to have a female companion: Miss Gregory, a cousin, usually fulfilled this role during the 1770s and later it was undertaken by her sister, Mary. Miss Gregory's importance in this regard was acknowledged by Lady Hardwicke, who wrote to her daughter in 1777 that she was 'very sorry you have no Companion there, as I also think it is really wanted in those Places, \& wish you may meet with any Person to make one'.22 This desire for female companionship was a widespread phenomenon. Laurence Stone has noted how chaperones were a common presence within wealthy circles, even during a couple's honeymoon, arguing 'The need for supportive female assistance in this time of psychological and physiological crisis shows how strong was the social attraction of each sex for its own company'.23

That the couple were visiting Tunbridge Wells in part because of a hope of improving their chances of conceiving a child is something that has to be inferred from their circumstances rather than a motivation explicitly divulged by Amabel. This absence of records is not unusual. As Rosemary Baird has noted, 'Women who could not have children were usually stoical, and barely, if ever, referred to it in their letters'.24 This trait has been corroborated by Blodgett, who has suggested that reluctance openly to refer to infertility extended further than not talking about it, stating; 'Women of the past wrote alone and kept taboo subjects hidden even from themselves.'25 Given the importance placed on children, especially amongst the elites who were concerned with the inheritance of titles and property, it is a safe assumption that after three years of marriage the couple had become anxious.

The Tunbridge Wells waters had a long-established reputation for promoting fertility. This originated with Queen Henrietta Maria, wife of Charles I, who had visited the fledgling spa in July 1629 to recuperate after the birth and death of a premature son. The chalybeate waters proved effective: Henrietta Maria recovered quickly and the following November she was reported to be pregnant again, giving birth to a healthy baby, the Prince of Wales, on 20 May 1630. This success was built upon by Lodowick Rowzee, who in 1632 published the spa's foundational text, The Queenes Welles, That is a Treatise on the Nature and Vertues of Tunbridge Water, which established the water's curative properties and how they were to be taken. Whilst not claiming the waters to be a panacea, Rowzee credited them with being able to cure a wide range of afflictions due to their effectiveness in removing 'obstructions'. Women's health was prominent within Rowzee's list of cures and he stated confidently of the water's powers: 'there is nothing better against barrenness and to make them fruitful'.26 The Stuarts, most notably Queen Anne, continued to use the waters to promote fecundity later in the seventeenth century, albeit with negligible success. 
Infertility would have been a concern for many of the women visiting spas during the seventeenth and eighteenth centuries, when approximately a quarter of all marriages were childless.27 Evidence on fertility in the early modern period suggests 'that most wives . . bore a child within the first two years of marriage' .28 Those women who struggled to conform to this trend faced a wide-range of pressures, including from their families who expected an heir and religion, which saw children as a sign of God's blessing.29 The marketing of mineral waters as a cure for barrenness, therefore, had the potential to result in a lucrative and consistent flow of hopeful patients. For those who did succeed in falling pregnant, the water cure offered safe delivery and speedy recovery after birth: 'None at this time doubted that childbirth itself. . . was a painful and dangerous ordeal.'30 However the focus lay on achieving conception and strengthening women to achieve successful pregnancy (i.e. not to miscarry) and recovery after birth rather than advising women to drink the waters whilst pregnant.

Women's health has been long recognised as an important aspect of taking the waters at Tunbridge Wells. As Barton's observed:

... the majority of married ladies at the Wells ... had come there for some intimate purpose. The childless were quite frankly taking the waters in order to conceive, the pregnant to ensure safe delivery, and others after disappointments have returned undaunted to get well and start all over again. 31

There was more to experience of women's health at Tunbridge Wells than the search for a medical cure, however. As Barton astutely noted, 'The treatment of gynaecological disorders presented no difficulties to the ... physician; whatever the trouble might be, the prescription - a visit to Bath or Tunbridge Wells - never varied or failed to earn him the gratitude of his patient.'32 There existed a sharp divide within literature's portrayal of taking the waters as a cure for infertility between the spa as a centre for healing and as a place of licentiousness and scandal, where the waters were used as a poorly constructed cover for extra-marital affairs. Satiric and literary portrayals of resort life frequently suggested that whilst many women left a watering place pregnant, this was not a result of the waters.

Amabel regularly drank the waters whilst at Tunbridge Wells and a letter written to her sister in 1775 is revealing of her habits and the perceived effects of the waters:

I began today to drink two Glasses (one at 9, \& the second at 1, ) \& find myself extremely well ... a little Headach now \& then. I am persuaded they are very good for 
me, since those hot Days, though the Sun was more scorching, oppress'd me much less, than the Heat at Wrest \& Wimple. Don't think I contradict myself, for Oppression \& a Head-ach, are so very different, that (luckily,) I never had a Head-ach that oppress'd me, in my Life. 33

Medical advice dictated that the waters were most effective when taken first thing in the morning on an empty stomach. Thus the routine promoted by guidebooks suggested taking the waters once a day before breakfast. However Amabel in 1775 drank the waters twice a day, which corroborates the theory that taking the waters was particularly important for her during this period. Unfortunately, there is no indication of whether she received medical advice (though it is likely that she did) which would have allowed a greater understanding of the regime being followed and the outcome hoped for.

ii

Amabel's second phase of resort visits demonstrates the role of the water cure in the pursuit of health. The picture that emerges, however, is not straightforward and the evidence suggests both a strong belief in the curative powers of mineral waters and doubts about their efficacy. This phase is comprised of two resort visits in the 1780s: to Margate in 1782 and Bath in 1784.

Boasting strong communications links with London via the River Thames, Margate had emerged as a leading seaside resort. Indeed, the town had been one of the first places in England to offer sea-bathing facilities when Thomas Barber advertised the opening of his seawater bath in 1736. Margate's initial development as a watering place was slow but from the 1760 s the town experienced a prolonged period of investment and expansion. Aiming to replicate the grand Palladian architecture of Bath and striving to create an aspirational environment that contained all the fashionable social, cultural and medical facilities deemed necessary by polite society, Margate gained assembly rooms, shops and visitor accommodations. Circulating libraries were central to Margate as a resort: not only was there a high concentration of establishments under competing proprietors - four in total during this period - but they acted as focal points for society. Alongside the lending of books, Margate's circulating libraries functioned as social centres, sellers of luxury goods and occasionally even hosted dance assemblies. The town's water communications with London, initially utilizing hoys, ships that had been used to transport corn to the capital, meant visitors could be transported quickly and cheaply from the city. This opened up the possibility of visiting the resort to a far wider portion of the population and soon Margate gained a reputation as the favoured destination of the 'city nobility'; London's middling orders. This did not mean, however, 
that the aristocracy and gentry ceased to visit and their patronage remained important to the continued popularity of the resort.

Amabel's visit, which lasted only one week between 27 July and 2 August 1782, was prompted by the declining health of her father Lord Hardwicke who in the following year would be seized by a paralytic disorder that seriously affected his arm and leg and would come to suffer from a variety of ailments including scorbutic eruptions and costive bowels. When Amabel's diaries entries from Margate are compared to those written at Tunbridge Wells, a number of differences can be seen between the pattern of daily life. First, there was less emphasis at Margate on the assembly rooms as a focus for the resort's social life and there is no indication that either a daily or weekly routine was being followed by visitors. In contrast to Tunbridge Wells where the assembly rooms were visited on almost a daily basis, at Margate Amabel mentioned them only once, when she went on 1 August 'with Miss Yorke to pay some visits, see the Rooms, go to some Shops \&c.'34 Lady Hardwicke likewise wrote in a letter written a couple of weeks earlier that 'There is a fine Assembly-Room but I don't hear of Company at it' but this was apparently due to their visit being slightly out of season, 'The High tide at this place being the Months of Augt \& Septr \& then I believe it is chiefly filled from the good City of London, \& Miss J.Y. did not I believe last year go to any Balls.'35 This comment is the only mention within the letters of either Lady Hardwicke or Amabel of the lower social reputation of Margate and though it may have prevented some of their acquaintance from patronizing some of the resort's social activities (Miss J.Y. appears to have avoided balls for this reason) it had certainly not prohibited their visiting the town. Of the resort architecture, the most frequently visited was the pier, with walking and visiting locations within the Isle of Thanet being Amabel's most common pastime. Destinations included Ramsgate where 'the View of Sandwich, the Downs, the very distant shore of Calais, is beautiful and the Pier a very handsome one, \& well built' and the small pleasure garden of Dandelion 'where there is a pretty Wood, \& a little Plantation of shrubs.'36

Margate was compared directly to Tunbridge Wells and Brighton by Lady Hardwicke in 1782. In general she was impressed with the resort, which was 'upon the whole less unpleasant in its situation than I expected, being more Country... the Views of the Sea are always fine \& amusing. In short I think it might be less tiresome upon the Whole for the Eyes than Brightne. [sic]'37 Amabel, too, debated the relative charms of each resort:

As I think you was not very fond of Brighthelmstone so I imagine you would not be fond of Margate. Which is the most tolerable is hard to decide. The Sea Views at Margate are much finer, as many more Vessels pass in Sight, \& the Drive to Kingsgate and Ramsgate 
may be call'd beautiful. The Country at Brighthelmstone is Downs for Pasture here it is open Cornfields which are remarkably fertile. The chief Inconvenience which struck me at Margate, was the want of such a clean open airy Walk near the Bathing Houses as the Steim [sic] and Cliff may be reckoned. 38

It is interesting to note that it was not the social, cultural or medical facilities such as assembly rooms and circulating libraries that Amabel used as her basis for comparison, instead she focused on the physical environment: the sea view, walks and surrounding countryside took prominence.

The family experienced a series of problems acquiring satisfactory accommodation. Lady Hardwicke complained 'We are not near so Well Lodged as at that Place' [Brighton] and 'The House first taken for us was Intolerable, \& we moved the next day into another.'39 Amabel faced similar problems when she arrived in Margate to join them: 'The Houses at Margate are better furnish'd than those at Tunbridge, but certainly smaller, as you know it was not difficult to lodge you there, \& it was quite impossible for Ld Hardwicke to lodge me.'40 This was most likely a result of Margate being still a fairly new resort where accommodation was a mixture of purpose-built facilities and converted pre-existing cottages.

Unfortunately, sea-bathing did not prove efficacious and Lord Hardwicke's health continued to decline. Pursuit of a cure led the family party to Bath in 1784. Amabel described her father's condition to Mary in a letter of 24 October:

I feel that on the whole his situation grows more \& more melancholy I do not believe he is worse in Essentials, excepting the increasing Costiveness of his Bowels, but his Spirits are greatly sunk from last Winter, when I us'd to wonder how they kept up so well. Perhaps he had then indulg'd some Hopes that his arm might be cur'd, now the Hopelessness of his Case seems to affect him greatly. 41

Neither Lord Hardwicke, nor his daughter held high hopes of curative properties of the Bath waters in this case. Perhaps accordingly, Lord Hardwicke proved reluctant to actually take the waters, to Amabel's consternation: 'As he had not the courage to set out for bath, so now he is come, he has not the Courage to begin Pumping. He has talk'd of it two or three Evenings, then feels himself wearied \& heavy, gives it up and goes to Bed.'42 As the following extract from a letter to Miss Gregory demonstrates, Lord Hardwicke's reluctance was a source of much worry and frustration for Amabel, yet she too was sceptical of the waters powers: 
I always hop'd I could say that my Father was settled into some regular Course of the Waters, but now I see less Chance of it than ever as he has been indispos'd for this Week past ... For the Preceding Week he had been pretty tolerable, but then what Use did he make of those Waters that he comes here for? He was always saying he would go to the Pump \& then as regularly putting it off . . I I have vex'd myself often enough at this, \& should have vex'd a good deal more if I had more faith in the Efficacy of these Waters in this Case. But as I have said often, I have not now any Faith in the Bath Waters, because he tried them the very Winter before his Limbs grew worse, $\&$ they did not keep off the Disorder \& Weakness. 43

Despite increasing competition from newly fashionable spas and seaside resorts, Bath remained the nation's premier watering place. The larger spa was able to offer visitors a much wider range of facilities and amusements than its smaller competitors and, despite Lord Hardwicke's health providing the impetus for this visit, Amabel was able to engage in a more diverse range of social and cultural activities than at either Margate or Tunbridge Wells. Daytime activities were divided between the Pump Room and with walks around the Crescent and Circus, as well as excursions further afield, such as to Prior Park. As a keen artist, opportunities were taken to view art exhibitions. On 29 October, Amabel 'Went to see Mr Hoare's Pictures', which were judged to display 'good Ideas of Beauty \& Composition but his colouring is apt to be too red \& glaring \& I should think his Drawing sometimes not correct'.44 Card parties, visits to the Baths and Pump Room to bathe in and drink the waters and excursions to points of interest in the surrounding countryside were also frequent activities. Thus, despite genuine concern over her father's health, Amabel was able to participate in a number of leisure activities during her stay. Unfortunately, however, the trip did not have the desired outcome: Lord Hardwicke's poor health continued until his death in May, 1790.

iii

Amabel's visits to Tunbridge Wells between 1790 and 1826, during which she was usually accompanied by her sister Mary, demonstrate how an individual's use and experience of a watering place could change over a lifetime. In revisiting Tunbridge Wells, a resort both sisters enjoyed in their youth, memory and comfort were significant: both were now widows (Mary's husband, Thomas Robinson, second Baron Grantham, had died in 1786) and were increasingly seeking secure leisure at a gentler pace in comfortable and familiar surroundings whilst the water cure promised to maintain their health as they progressed through middle to old age. 
The Countess visited Tunbridge Wells twice in the early 1790s, each time for approximately a month: from 23 August to 23 September 1790 and 18 June to 2 August 1792 . Between 1807 and 1826 Amabel visited Tunbridge Wells six times, each time for approximately a month starting late June / early July and ending late July / early August. Amabel, as a widow of thirty-nine found Tunbridge Wells of 1790 a much different place from that she had first visited in 1775 as a newly married young woman of twenty-four. Reminiscing about visits to the spa in her youth and judging the present unfavourably by comparison, was a common theme within Amabel's surviving letters from this period and the early 1790 s in particular. This was demonstrated clearly in the opening quotation of this article, where the Countess was very disparaging about the spa's society, facilities and even the weather.

By the end of the eighteenth century, Tunbridge Wells had reached maturity as a resort and was transitioning into a centre of residential leisure. Whilst one guidebook placed a positive spin on this, claiming of the spa that 'its customs are settled, its pleasures regulated, its markets and all other conveniences fixed', in reality stagnation had set in.45 Profits from the shops along the Parade and assembly rooms were declining and instead of relying on elite visitors, the spa was increasingly dependent on the growing numbers of retired businessmen and single women who would buy one or two houses in the resort and come as residents for during the summer every year.46 Accordingly, the character of the spa and the nature of its amusements changed to accommodate these new patrons as the number of fashionable visitors declined. During the first half of the nineteenth century, the town's permanent population grew rapidly: from c. 1,200 in 1800 to 5,929 in 1831.47

As Amabel grew older, her habits changed. A common theme of these later visits to Tunbridge Wells was a preoccupation with the weather. Hot, wet and stormy weather were all causes for concern, whilst a thermometer on the Walks was frequently consulted. On 30 June 1826, for instance, Amabel noted 'Hot Weather though not as hot as Monday \& Tuesday when the Thermometer was above $80, \&$ I believe it is now about $75^{\prime}$ and mentioned that she was 'thankful for having escap'd' 'severe Storms' earlier in the week'.48 In contrast with her earlier visits, Amabel made fewer visits to the assembly rooms, only rarely attending dance assemblies, preferring instead to spend much of her time walking and driving around the countryside and visiting friends. Amabel's passion for politics remained, however and topical political issues, as reported by newspapers, featured prominently in her diary entries during this time. During her final visit to Tunbridge Wells in 1826, this was particularly evident. On 1 July, for example, Amabel mentioned how 'Some Newspapers talk much of Riots at Irish Elections', whilst on 11 July, she commented on the implications of the King of Portugal's death.49 
Amabel's dissatisfaction with the spa did not just result from its altered character: it also derived from her changing expectations and motivations for visiting. Not only had the novelty of resort life worn off but the society found at the resort was judged inferior to that of the past and it is unsurprising that it was during these years, rather than the 1770s that Amabel complained of boredom. Visitors to Tunbridge Wells had complained of boredom throughout the eighteenth century. John Macky, describing the spa in 1714, stated: 'THE Manner of living at Tunbridge is very Diverting for one Week; but as there is no other Variety but in new Faces, it soon proves Tiresome to a Stranger.'50 Mid-century, Elizabeth Montagu offered similar sentiments, noting wryly in a letter, 'Since I last wrote to you we have had a change of persons but not of amusements.'51 Amabel in 1791 faced a similar predicament, complaining, 'I have nothing at all, at all to say. This place has hitherto been most exemplarily sober \& dull.'52 Boredom was one way in which visitors expressed their dissatisfaction with the spa's social and cultural facilities and thus was a means through which individuals challenged, perhaps unknowingly, the fashionable image of Tunbridge Wells. However, despite the frequency and prominence of such remarks and though boredom has been accepted as a 'central motif of spa literature and memoirs' from the nineteenth century, no studies of eighteenthcentury Tunbridge Wells have recognized its significance as an important facet of resort life. 53

As a cultural construct first emerging in the early modern period, 'boredom' in this historical context has been defined by Patricia Meyer as something 'that appears to be caused by not having enough to do, or not liking the things one has to do, or existing with other people or a setting one finds distasteful,' with the caveat that 'the definition of "not having enough to do" . . . depends on perception'.54 Why did visitors find Tunbridge Wells boring? Not only was boredom an inevitable result of the new expectations of leisure but the possibility of boredom was deeply ingrained within the structure of resort life. This resulted from three factors: the relatively small size of the spa, the highly structured daily and weekly regimen and the long average duration of stay. Looking back to the quotations that opened this discussion, the repetitiveness of resort life formed the focus of complaint and it is easy to imagine that following the same daily and weekly routine in such a small arena could become tiresome. It was not just of Tunbridge Wells that these complaints were made: Montagu wrote of Bath in 1740: 'The waters are employing the morning, visits the afternoon, and we saunter away the evening in great stupidity. I think no place can be less agreeable; How dy'e do? is all one hears in the morning, and What is trumps? in the afternoon.' 55 In this instance, boredom likewise derived from the repetitiveness of the entertainments but the people participating in them were also to blame for their acceptance of the routine and endless parroting of the same conversations. There can also be detected the desire of this prominent Bluestocking to separate herself from the homogeneous mass of the visiting company with their predictable conversations 
and the routine social round.56 The affectation of boredom by the fashionable elite was thus one response to the growing middling class participation in high status leisure activities.

How women expressed boredom was almost as important as the emotion itself. 'Trained to please others, [and] display constant anxiety about "entertaining" the readers of their letters,' and believing that 'to be bored or boring registers moral failure' women tried to make otherwise dull letters entertaining by 'insist[ing] on the interest of their routine experience' and, consciously injecting interest into their everyday lives even if 'they had to make something out of nothing.'57 This literary device can be clearly identified in a letter written by Amabel, from Tunbridge Wells in 1791 at what was supposedly the opening of the spa's summer season:

Though many People are dispers'd about in the different Lodgings yet they hardly meet upon the Walks, \& not at all at the Rooms. My Tyson who still hobbles on through the very little Business this Place affords, made an Attempt last Night to collect us all together \& open the Season with a Public Tea-drinking, but it was very empty \& very dull; one little Incident only made us laugh, a Kitten got into the Music-Gallery (where there was no Music) \& set up a most piteous Mewing, \& some of the Company clapp'd it as a very fine Italian Singer. 58

But there was more to this expressions of boredom than a desire to entertain. Amabel's letter commented on the lack of cohesion and expressed dissatisfaction with the conduct of society: she frequently complained that Tunbridge Wells was no longer the exciting, entertaining place she had visited in her youth. Sympathizing with Amabel's displeasure, Miss Gregory offered the following counsel:

I am much obliged to you for your Letter am sorry that Tunbridge Well, is not so agreeable as formerly, but I believe in a course of years, ones own Ideas alter, and Novelty is said to have powerful Charms, yet I still think, you may perhaps when least expected meet with some agreeable people, for the remainder of you stay, I wish you may. 59

Thus age and nostalgia were strong factors contributing to Amabel's dissatisfaction, a fact recognized by Mary, who wrote to her sister in 1825: 'I fear as a residence Tunbridge cannot now be what it was to us, in earlier days.'60 But why, if Tunbridge Wells was tiresome and dull, did Amabel and Mary keep going back and what importance should be given to expressions of boredom? The 
answer must be that the negative aspects of resort life were outweighed by the positive and it seems likely that Amabel found a certain enjoyment in voicing her complaints. Furthermore, the continued visits suggest a generational link with individual resorts. Though fashion may have moved away from this increasingly residential spa, the generation who had attended during its heyday continued to visit their old haunts.

iv

Amabel began the twentieth volume of her diary by saying 'volumes follow volumes \& crowd my Drawers with little use to myself \& still less to other People.'62 On the contrary, it has been argued that her records are an invaluable source that provide insight into the visitor experience of watering places. Across different stages of her lifecycle, the way Amabel used resorts and the resorts themselves changed, according to the intersecting factors of age, marital status, health and personal character. As a newly married young women seeking fashionable diversion and a treatment for her infertility; a concerned daughter searching for medical care for her ailing father and a wealthy independent widow, Amabel approached and used resorts in different ways. Those aspects of resort life Amabel chose not to engage with are as important as those she in which she did: unlike many of her fellow visitors to the spa and seaside, Amabel was not an active participant in the marriage market (either looking for a suitor herself or as a 'matchmaking mama' searching for an eligible match for her children); neither was she a fortune hunter, gambler or fashionable sufferer of excessive sensibility. Whilst Amabel's motivations, activities and reflections as an elite, highly educated and unusually independent woman were unique to her, the insight gained into the relevance of the female lifecycle to the visitor experience of watering places, particularly with regards to the use of waters to combat infertility and how the use of resorts changed with age, can be applied more widely to elite women across this period. 
1. Bedfordshire and Luton Archives and Record Service (BLA), Wrest Park (Lucas) MS, 'Amabel Hume-Campbell, Countess De Grey to Mary Jemima Robinson, Baroness Grantham, 29 Aug. 1790. L30/12/93.

2. Amabel anonymously published two books, An Historical Sketch of the French Revolution from its Commencement to the Year 1792, and An Historical Essay on the Ambition and Conquests of France, with some Remarks on the French Revolution, published in 1792 and 1797 respectively. Both publications appear to have been well received, though neither was a best-seller. She also published at least two pamphlets on current political affairs.

3. West Yorkshire Archives Service, Leeds (WYL), Vyner of Studley Royal, Family and Estate Records, Dairies of Lady Amabel Yorke, vol. 1, p. 1.

4. See in particular Joyce Godber, The Marchioness Grey of Wrest Park (Bedford, 1968).

5. Harriet Blodgett, Centuries of Female Days: English Women's Private Diaries (Gloucester, 1989), p. 41; p. 16.

6. Amanda Vickery, The Gentleman's Daughter: Women's Lives in Georgian England (New Haven, Conn., 1998), p. 60.

7. Ibid, p. 60.

8. Amanda E. Herbert, Female Alliances: Gender, Identity, and Friendship in Early Modern Britain (New Haven, 2014), p. 117; 141.

9. Alison E. Hurley, 'A Conversation of Their Own: Watering-Place Correspondence among the Bluestockings,' Eighteenth-Century Studies, 40.1 (2006), 1-21.

10. R.S. Neale, Bath 1680-1850: A Social History, Or, A Valley of Pleasure, Yet a Sink of Iniquity (London, 1981); Peter Borsay, The Image of Georgian Bath, 1700-2000: Towns, Heritage and History (Oxford, 2000); Graham Davis and Penny Bonsall, A History of Bath: Image and Reality (Lancaster, 2006). 
11. Audrey Heywood, 'A Trial of the Bath Waters: The Treatment of Lead Poisoning' in The Medical History of Waters and Spas, ed. by Roy Porter (London, 1990), pp. 82-101.

12. Alan Savidge, Royal Tunbridge Wells: A History of a Spa Town, revised by Charlie Bell (Tunbridge Wells, 1995); C.W. Chalklin, Royal Tunbridge Wells: A History (Chichester, 2008).

13. Margaret Barton, Tunbridge Wells (London, 1937).

14. John Whyman, The Early Kentish Seaside (1736-1840): Selected Documents (Gloucester, 1985)

15. J.A.R. Pimlott, The Englishman's Holiday: A Social History (Hassocks, 1976); Phyllis Hembry, The English Spa 1560-1815: A Society History (London, 1990); John K. Walton, The English Seaside Resort: A Social History, 1750-1914 (Leicester, 1983); James Walvin, Beside the Seaside: A Social History of the Popular Seaside Holiday (London, 1978).

16. Roy Porter, Bodies Politic: Disease, Death, and Doctors in Britain, 1650-1900 (Ithaca, 2001), pp. 167-169.

17. See in particular: Clark Lawlor, "'It is a Path I have Prayed to Follow": The Paradoxical Pleasures of Romantic Disease,' in Romanticism and Pleasure, ed. by Thomas H. Schmid and Michelle Faubert (New York, 2010), 109-32 (p. 109); Heather R. Beatty, Nervous Disease in Later Eighteenth-Century Britain: The Reality of a Fashionable Disorder (London, 2012), p. 96.

18. Richard Onely, A Description of Tunbridge-Wells (London, 1771), p. 19.

19. 'Extract of a Letter from Plymouth', Gazetteer and New Daily Advertiser, 31 July 31 1775, p.2.

20. WYL, Diaries of Lady Amabel Yorke, vol. 4, pp. 126-127.

21. BLA, 'Amabel Hume-Campbell, Countess De Grey to Mary Jemima Robinson, Baroness Grantham', 24 Aug. 1775. L30/13/12/30.

22. BLA, 'Jemima Yorke, Marchioness Grey to Amabel Hume Campbell, Countess de Grey', 4 Jun 1777, L30/11/122/121.

23. Lawrence Stone, The Family, Sex and Marriage in England 1500-1800, abridged edn (Harmondsworth, 1982), p. 224.

24. Rosemary Baird, Mistress of the House: Great Ladies and Grand Houses, 1670-1830 (London, 2004), p. 14.

25. Blodgett, Centuries of Female Days, p. 40.

26. Lodowick Rowzee, The Queenes Welles: That is, a Treatise of the Nature and Vertues of Tunbridge Water (London, 1632), p. 48.

27. Anne Laurence, Women in England, 1500-1760: A Social History (London, 1994), p. 42.

28. Angus McLaren, Reproductive Rituals: The Perception of Fertility in England from the Sixteenth to the Nineteenth Century (London, 1984), p. 32.

29. Ibid, p. 32. 
30. Antonia Fraser, The Weaker Vessel: Woman's Lot in Seventeenth-Century England (London, 1984), p. 69.

31. Barton, Tunbridge Wells, p. 149.

32. Ibid, p. 149.

33. BLA, 'Amabel Hume-Campbell, Countess De Grey to Mary Jemima Robinson, Baroness Grantham', n.d. c.1775. L30/13/12/29.

34. WYL, Diaries of Lady Amabel Yorke, vol.7, p. 134.

35. BLA, 'Jemima Yorke, Marchioness Grey to Mary Jemima Robinson, Baroness Grantham', 17 Jul. 1782. L30/13/9/54.

36. WYL, Diaries of Lady Amabel Yorke, vol. 7, pp. 133-34.

37. BLA, 'Jemima Yorke, Marchioness Grey to Mary Jemima Robinson, Baroness Grantham', 17 Jul. 1782. L30/13/9/54.

38. BLA, 'Amabel Hume-Campbell, Countess De Grey to Jemima Mary Gregory', 1 Sept. 1782. L30/23/50.

39. BLA, 'Jemima Yorke, Marchioness Grey to Mary Jemima Robinson, Baroness Grantham', 17 Jul. 1782. L30/13/9/54.

40. BLA, 'Jemima Yorke, Marchioness Grey to Mary Jemima Robinson, Baroness Grantham', 17 Jul. 1782. L30/13/9/54.

41. BLA, 'Amabel Hume-Campbell, Countess De Grey to Jemima Mary Gregory', 24 Oct. 1784. L30/13/12/96.

42. Ibid.

43. BLA, 'Amabel Hume-Campbell, Countess De Grey to Jemima Mary Gregory', 15 Nov. 1784. L30/23/55.

44. WYL, Diaries of Lady Amabel Yorke, vol.8, pp. 95-6.

45. Anon., The Tunbridge Wells Guide (Tunbridge Wells, 1780), p. 44.

46. Chalklin, Royal Tunbridge Wells, pp. 35-6.

47. Ibid, p. 39.

48. WYL, Diaries of Lady Amabel Yorke, vol. 37, p. 164.

49. Ibid, p. 165.

50. John Macky, A Journey Through England. In Familiar Letters from a Gentleman Here, to his Friend Abroad (London, 1714), p. 57.

51. Elizabeth Montagu, The Letters of Mrs. Elizabeth Montagu, with some letters of her correspondents, vol. 3 (London, 1809-13), p. 89.

52. BLA, 'Amabel Hume-Campbell, Countess De Grey to Jemima Mary Gregory', 24 Jul. 1791. L30/23/98. 
53. David Blackbourn, 'Fashionable Spa Towns in Nineteenth-century Europe' in Water, Leisure \& Culture: European Historical Perspectives, ed. by Susan C. Anderson and Bruce H. Tabb (Oxford, 2002), pp. 9-22 (p. 20).

54. Patricia Meyer Spacks, Boredom: The Literary History of a State of Mind (London, 1995), p. 27.

55. Elizabeth Montagu, The Letters of Mrs. Elizabeth Montagu, with some letters of her correspondents, vol. 1 (London, 1809-13), p. 73.

56. It is also likely that many elite women, who would have typically be occupied running large estates, would have welcomed the relaxed pace of resort life.

57. Spacks, Boredom, pp. 103-6.

58. BLA, 'Amabel Hume-Campbell, Countess De Grey to Jemima Mary Gregory', 29 Jun. 1791. L30/23/97.

59. BLA, 'Amabel Hume-Campbell, Countess De Grey to Jemima Mary Gregory', 29 Jun. 1791. L30/23/97.

60. BLA, 'Esther Hill to Amabel Hume-Campbell, Countess De Grey', 5 Sept. 1790. L30/11/121/27.

61. BLA, 'Mary Jemima Robinson, Baroness Grantham to Amabel Hume-Campbell, Countess De Grey', 2 Jul. 1825. L30/11/240/328.

62. WYL, Diaries of Lady Amabel Yorke, vol.1, p. 2. 